\title{
The Influence of Interpesonal Communication, Organizational Culture of Teacher Organizational Commitment in Madura
}

\author{
Abdul Hobir ${ }^{1}$, Ava Swastika Fahriana ${ }^{2}$ \\ Universitas Islam Madura, Indonesia $^{1}$ \\ UIN Maulana Malik Ibrahim, Malang, Indonesia ${ }^{2}$ \\ \{hobir6288@gmail.com ${ }^{1}$, avaswatika13@gmail.com $\left.{ }^{2}\right\}$
}

\begin{abstract}
This study aims to know the influence of interpersonal communication, organizational culture on organizational commitment. This study is a quantitative study with survey method. The population of this study is 175 teachers in a state senior high school using total sampling technique. The instrument of this study is questionnaire with Likert scale. The data was done and analyzed using path analysis which begins with analysis reservation test include normality test through Chi-square test, homogeneity test through Barlet test, and long test and Significance Test for Regression. The results show: 1) the direct interpersonal communication influence the organizational commitment with coefficient stripe 0.592. 2) The right corporate culture influences the organizational commitment with the coefficient stripe 0.405 .3 ) Interpersonal communication and regulatory culture influence simultaneously to the organization commitment 0.972 . The conclusion of this study is interpersonal communication, and organizational culture give direct simultaneously and partial influence on teacher organizational commitment. The implication of this study is as effective the interpersonal communication with well organization culture, as high the teacher organization commitment.
\end{abstract}

Keywords: Organization Commitment, Interpersonal Communication, Organization Culture.

\section{Introduction}

Proclamation enthusiasm 17 August 1945 is very enlivened for organizer "Nation Education Congress" on 25 of November 1945 in Solo City, Central Java, and for God's mercies and blessing from this congress found "Indonesia Republic Teacher Association" or (PGRI) in short, which is the association of all teachers throughout Indonesia.

At the end of 2015, all the leaders of ASEAN country attended High Stage Conference (KTT) -26 ASEAN. The 26 KTT has been dealt with cooperation declaration process ASEAN and an effort to make a new community that is Asean Economic Society (MEA). As a consequence of the application of MEA, there will be a free flow of labor market, luggage, services, capital, and investment among countries in the ASEAN region. This condition will 
be an opportunity and a challenge that must be faced by all Indonesian, especially teachers of PGRI member who has a central role in building nation.

Anticipating rapid changes and increasingly large and complex challenges, there is another way for PGRI except working on increasing teachers ' competitiveness and academic products and another service on it, one of them should be achieved through improving standard education. Only by giving the right education, this nation can release the society from multidimensional crisis shackle continuously. Through education, this nation can release society from its slump.

According to Surya in Kunandar that a professional teacher will reflect on implementing tasks devotion, mark with the proficiency whether the theory or method [1]. On the other hand, it is shown through his/her responsibility in implementing all his/her devotion. A professional teacher should be able to bear his/her responsibility of individual, social, intellectual, moral and spiritual. Then, Udin explained that the characteristics of professional teacher, such: (1) they have committed for organization or commitment for students' learning process; (2) the master in material and how they apply or teach; (3) they are able to think systematic for what they do and learn from their experience; and (4) they are a part of learning society in their passion to be able to have chance to increase their professionalism [2].

The explanation above shows that professional teacher must have high commitment organization, which is marked with his/her interest in a member of the organization, value and the objective of the organization, hard work in an organization to create the goals of education.

According to Luthans organizational commitment is a strong desire to be constant as an organizational member, the desire of struggling that appropriate with the organization, certain certainty, and receiving value and objective of an organization [3]. In other words, it is a loyalty reflective attitude member to organization and process continuously dynamic organization members. The larger theoretical organizational commitment study and comprehensive as stated by Colquitt, LePine, and Wesson, this theory argued that commitment organization is defined as employee's desire to tied up in the organization [4].

There are some aspects that influence commitment. Kreitner and Kinicki argued that organizational commitment fluctuates the factor that influences it, such: (1) phycology and social, included ego defense, individual motivation, and pressure of colleague; (2) organization, included communication and internal situation organization; (3) project characteristic is postponement infestation feedback; and (4) contextual is pressure of politic external [5]. However, Baron and Green explains that factors which define the degree of individual commitment, they are: (1) as high the degree of responsibility and autonomy gave to people for doing their jobs, the more fascinating job people have the higher their commitment; (2) as big the job chance outside, will cause as low the commitment; (3) individual characters, like fed up of a job also give the influence of their commitment; (4) situation or organization culture, like good personality from the leader, can make the commitment of their employees higher, thus the organization caution of peace [6].

Based on Kreitner and Kinicki explanation and Baron and Greenberg, it is known that organizational culture and communication are the factors that can influence organizational commitment. This explanation relates to teacher acts as the communicator needs the ability to communicate well, as the model teacher should have organization culture well; and as motivator teacher should have high achievement motivation.

One factor that also influences the commitment and also well cooperation building is well communication between elements in that organization. Well, communication will bring each understanding and comfort in work. Effective communication is needed to arouse the organization, as effective the communication as productive the attitude of the members to do 
this work. Introducing the mechanism of this organization culture surely is not in direct, but it needs the process of communication through some interactions that happened in every part of the organization.

The basic of commitment, senior high school teacher, should have high organization commitment and has strong desire as members of PGRI organization, the desire to hard work to create the organization's goal, and certainty and receiving value and objective of the organization.

However, based on the fact that the Indonesian people are still faced with problems of elementary to high school teachers who are less able to perform the task professionally. The result of Philip Suprastowo`s study about absent teacher rate in 20 regency/city in Indonesia also finds that teachers' absence rate attain to $6.6 \%$ and absent teacher dominantly Public Servant (PNS)and has been certificated. The main cause of absent teacher is agency duty and kinds of necessity with official allowance. However, in the result of that Teacher absence rate still found the effect why teachers do not attend as $2.8 \%$ gets punishment, $2.38 \%$ teaching not based on the schedule, $2.38 \%$ coming late, $1.19 \%$ doing another duty, $1.19 \%$ coming back earlier. From the variation of reasons why teacher absent shows that teacher less give more attention for their discipline to the organization and it proves that teacher organization commitment is still low [7].

Based on the statements above, it is known that there is positive and negative indicator related to teacher commitment to PGRI organization in Madura. Therefore, to study about teacher organization commitment in PGRI, especially organization commitment from state senior high school in Madura, so it is needed a study about some factors that can predict or control that organization commitment.

Based on the explanation above, so this study can be defined to know: (1) the direct interpersonal communication influence to teacher organization commitment; (2) the direct organization culture influence to teacher organization commitment; (3) the direct interpersonal communication, organization culture influence simultaneously to teacher organization commitment.

\section{Literature review}

\subsection{Organizational Commitment}

The term commitment in an organization is always a study to extend employees activities to the aim of the organization can be obtained effectively and efficiently, so the concept of organizational commitment can appear. Robbins and Coulter argued that organizational commitment is how far an employee identifies the organization and the objective also how to preserve their members in an organization [8]. According to Mowday, organizational commitment is the crucial attitude dimension which can be used to assess employee tendency to hold out as a member of the organization. Organizational commitment is an involvement attitude and individual loyalty in an organization. Luthans explained that organization commitment as attitude is: (1) strong desire to be an organization member; (2) a desire to hard work for fitting organization`s hope; (3) specific certainty, receiving value and the objective of the organization [3].

Colquitt, LePine suggest the larger organizational commitment theory and comprehension, and Wesson, this theory argued that organizational commitment could be defined as employee desire to be in an organization. Organization commitment that argued by Colquitt, LePine, and Wesson is related by some factors that can influence it. There are four big groups' factors that 
define organizational commitment; they are the individual mechanism, individual characteristic, group mechanism (group), and organism mechanism. The direct factor that defines organization commitment is an individual mechanism include work satisfaction factor, stress, motivation, belief, justice, ethic learning and taking a decision [4].

While the indirect factor that influences organizational commitment through individual mechanism is mechanism organization factor includes organization culture factor and organization structure, group mechanism factor includes force factor and leadership attitude, strengthen and leadership influence, process, team communication, and individual characteristic factor that establish from culture, personality and capability value. This last factor gives big direct influence to the individual machines and it gives direct influence to organizational commitment. Based on this paradigm it can be known that each factor has correlation each other's to determine the organizational commitment. Based on the integration theory from Colquitt, LePine, and Wesson above, organization mechanism, team mechanism, individual characteristic build up individual mechanism as an effort to spring up performance and organizational commitment. Another word, the formation of organization commitment depends on the individual mechanism that is influenced by organization mechanism, team mechanism, and individual characteristic.

\subsection{Interpersonal Communication}

According to Julia, the best definition of interpersonal communication is focus on what happens among people, not where are they or how many people attend [9]. According to Solomon and Jennifer interpersonal communication more intend to special communication that happened around people and create personal bond between them [10].

De Vito argued that interpersonal communication is taking and giving messages among two people or in the small group of people, with five characterizes bellow: (1) openness; (2) empathy; (3) support; (4) positive thinking; (5) equality.

Additionally, Evert M. Rogers in Depar mentioned some interpersonal communication characteristics, as such: (1) the current message inclines on two ways; (2) communication context is face-to-face; (3) high-rate feedback; (4) ability to solve the very-high selectiveness level; (5) speed to reach the big target is slow; and (6) the effect occurred such as attitude [11].

Interpersonal communication is very crucial in an organization. The importance of interpersonal communication as the interaction forming between the speakers and their interlocutors will construct the mutual understanding, respecting each other, appreciating each other based on the awareness that human is proper, deserve, and compulsory to be appreciated and honored as a human. According to Borger in Morissan, when we have communication, we make a plan to reach our goals [12]. Whereas Robbins stated that interpersonal communication is very important for it supports communication fluency in the organization [13]. Communication system and good interpersonal relation will minimalize discrepancy between some sides in the organization and minimalize unfaithfulness and distrustfulness in work environment.

\subsection{Organizational Culture}

According to Kreitner, organizational culture is a belief owned by (collective) together (declared or explicit) between organization members [14][15]. While Robbins and Judge pointed out that organizational culture refers to togetherness meaning system believed by the organization members which differ an organization with the others. 
According to KreitnerdanKinicki, the function of organizational culture is very important in organization life, such as (1) giving the member's organization identity, (2) Facilitating organizational commitment, (3) Promote the social system stability, (4) forming behavior by helping the members comprehend their environment [5] whereas Schein said that organizational culture aimed at helping the organization members to assimilate with their external environment by strengthening the organization members' understanding, ability to realize the mission, strategies, purposes, ways, and evaluation.

\section{Method}

This study applied a quantitative approach using survey design. The study was conducted at State senior high school in Madura Island. The populations were all 175 teachers in State Senior High School 1 in Madura Island. The sample in this study was taken using the nonprobability technique that is saturation sample or interchangeably as total sampling. 30 from 175 people as the experimental sample and 145 people as the research sample.

The data collected using questionnaire which was given to the respondents in the form of checklist multiple choice based on Likert scale model. The instruments, however, were tested before conducting the real research. The hypothesis testing used regression analysis and path analysis and had been tested to taste the standard coefficient using Chi-square, homogeneity test and Barlett test. Collinearity Statistic using Variance analysis to test Linear Regression with the standard coefficient of $\alpha=0.05$.

\section{Result and discussion}

\subsection{Result}

Data description which sets out in this chapter including Interpersonal Communication variable (X1) data, Organizational Culture (X2) and Organizational Commitment (X3). Those data are attained quantitatively from respondents' answers based on the questionnaires distributed to senior high school teachers as the sample of the study. The amount of the distributed questionnaires are 145 sets dealing with the amount of the sample. The description of each variable served on the summary in Table1.

Table 1. Description of Research Variable Data

\begin{tabular}{llr|r|r}
\hline & \multicolumn{1}{c}{$\begin{array}{c}\text { Interpersonal } \\
\text { Communication (X1) }\end{array}$} & $\begin{array}{c}\text { Oraganizational } \\
\text { Culture (X2) }\end{array}$ & $\begin{array}{c}\text { Organizational } \\
\text { Commitment (X3) }\end{array}$ \\
\hline $\mathrm{N}$ & Valid & 145 & 145 & 145 \\
& Missing & 0 & 0 & 0 \\
Mean & 149.0069 & 152.0276 & 139.7448 \\
Median & 147.0000 & 153.0000 & 141.0000 \\
Mode & 147.00 & 154.00 & 142.00 \\
Std. Deviation & 13.22692 & 12.30625 & 10.42085 \\
Variance & 174.951 & 151.444 & 108.594 \\
Range & 54.00 & 52.00 & 43.00 \\
Minimum & 123.00 & 124.00 & 117.00 \\
Maximum & 177.00 & 176.00 & 160.00
\end{tabular}


Sum

21606.00

22044.00

20263.00

The summary of normality with the Chi-square test is shown in Table 2 below.

Table 2. Normality Calculation on Chi-Square Test

\begin{tabular}{|c|c|c|c|c|c|c|}
\hline \multirow{2}{*}{ Number } & \multirow{2}{*}{ Normality Test } & \multirow{2}{*}{$\begin{array}{l}\text { Number of } \\
\text { Samples }\end{array}$} & \multirow{2}{*}{$\mathrm{Dk}$} & \multicolumn{2}{|r|}{$\chi^{2}(0,05)$} & \multirow{2}{*}{ onclusion } \\
\hline & & & & $\chi_{\text {table }}^{2}$ & the calculated $\chi^{2}$ & \\
\hline 1 & $\begin{array}{l}\text { Interpersonal } \\
\text { Communication } \\
\left(\mathrm{X}_{1}\right)\end{array}$ & 145 & 7 & $\begin{array}{c}14,01 \\
7\end{array}$ & 13,22 & $\begin{array}{c}\text { Normal } \\
\text { Distribution }\end{array}$ \\
\hline 2 & $\begin{array}{l}\text { Organizational } \\
\text { Culture }\left(\mathrm{X}_{2}\right)\end{array}$ & 145 & 7 & $\begin{array}{c}14,01 \\
7\end{array}$ & 12,53 & $\begin{array}{c}\text { Normal } \\
\text { Distribution }\end{array}$ \\
\hline 3 & $\begin{array}{l}\text { Organizational } \\
\text { Commitment }\left(\mathrm{X}_{3}\right)\end{array}$ & 145 & 7 & $\begin{array}{c}14,01 \\
7\end{array}$ & 11,56 & $\begin{array}{c}\text { Normal } \\
\text { Distribution }\end{array}$ \\
\hline
\end{tabular}

Prerequisite data on normal distribution if the calculated $\chi^{2}<\chi^{2}$ table

The summary of homogeneity with Barlett test is shown in Table $\mathbf{3}$ below.

Table 3.The Result of Homogeneity Variant Test

\begin{tabular}{|c|c|c|c|c|c|c|}
\hline \multirow[b]{2}{*}{ Number } & \multirow{2}{*}{$\begin{array}{c}\text { Variant } \\
\text { Homogeneity } \\
\text { Test }\end{array}$} & \multirow{2}{*}{$\begin{array}{l}\text { Number } \\
\text { of } \\
\text { Samples }\end{array}$} & \multirow[b]{2}{*}{$\mathrm{dk}$} & \multicolumn{2}{|r|}{$\chi^{2}(0,05)$} & \multirow[b]{2}{*}{ Conclusion } \\
\hline & & & & $\chi_{\text {table }}^{2}$ & the calculated $\chi^{2}$ & \\
\hline 1 & $\begin{array}{l}\mathrm{X}_{3} \text { is grouped on } \\
\mathrm{X}_{1}\end{array}$ & 145 & 93 & 116,511 & 63,869 & Homogeneous \\
\hline 2 & $\begin{array}{c}\mathrm{X}_{3} \text { is grouped on } \\
\mathrm{X}_{2}\end{array}$ & 145 & 95 & 118,751 & 70,626 & Homogeneous \\
\hline
\end{tabular}

Homogeneity prerequisite the calculated $\chi^{2}<\chi^{2}$ table

The summary of linear regression variable testexogenous variable on endogen is shown in

Table 4.

Table 4. The Result of Linear Regression Test

\begin{tabular}{|c|c|c|c|c|c|c|c|}
\hline \multirow{2}{*}{$\begin{array}{l}\text { Numb } \\
\text { er }\end{array}$} & \multirow{2}{*}{$\begin{array}{c}\text { Exogenous Variables } \\
\text { on } \\
\text { Endogen Variables }\end{array}$} & \multicolumn{3}{|c|}{ Linear Test } & \multicolumn{3}{|c|}{$\begin{array}{c}\text { Significance Test for } \\
\text { Regression }\end{array}$} \\
\hline & & $\mathrm{F}_{\mathrm{h}}$ & $\mathrm{F}_{\mathrm{t}}$ & Status & $\mathrm{F}_{\mathrm{h}}$ & $\mathrm{F}_{\mathrm{t}}$ & Status \\
\hline 1 & X1 with X3 & 0.64 & 1.49 & Linear & $\begin{array}{c}3154 \\
8\end{array}$ & $\begin{array}{c}3.9 \\
1\end{array}$ & $\begin{array}{l}\text { Very } \\
\text { Significant }\end{array}$ \\
\hline 2 & X2 with X3 & 0,22 & 1.49 & Linear & $\begin{array}{c}2202, \\
6\end{array}$ & $\begin{array}{c}3.9 \\
1\end{array}$ & $\begin{array}{c}\text { Very } \\
\text { Significant }\end{array}$ \\
\hline \multicolumn{2}{|c|}{ Level of Significance $\alpha=0.05$} & \multicolumn{3}{|c|}{$\begin{array}{c}\text { Collinearity Statistic } \mathrm{F}_{\text {hit }}< \\
\mathrm{F}_{\mathrm{tab}}\end{array}$} & \multicolumn{3}{|c|}{$\begin{array}{c}\text { Standard Coefficient: } F_{\text {hit }} \\
>>F_{\text {tab }}\end{array}$} \\
\hline
\end{tabular}


The summary of the decomposition of the regression coefficient is the direct effect and the total effect of $X_{1}, X_{2}$, on $X_{3}$ which is going to be summarized in Table 5 below.

Table 5. The Summary of Decomposition of Path Coefficient on Partial Effect, Total Effect of $\mathrm{X}_{1}, \mathrm{X}_{2}$ on $\mathrm{X}_{3}$

\begin{tabular}{|c|c|c|c|}
\hline \multirow{2}{*}{ Number } & \multirow{2}{*}{ Variable Effect } & Causal Effect & \multirow{2}{*}{$\begin{array}{l}\text { Residual } \\
\mathrm{e}_{1}\end{array}$} \\
\hline & & Direct & \\
\hline 1 & $\mathrm{X}_{1}$ on $\mathrm{X}_{3}$ & 0,592 & - \\
\hline 2 & $\mathrm{X}_{2}$ on $\mathrm{X}_{3}$ & 0,405 & - \\
\hline 3 & $\mathrm{X}_{1}, \mathrm{X}_{2}$ on $\mathrm{X}_{3}$ & 0,972 & 0,028 \\
\hline
\end{tabular}

Based on the path of coefficient prices result, the path diagram is the fixed model or theoretical model which links the research causal variables to conclude the organizational commitment of senior high school teachers shown in picture 1 below.

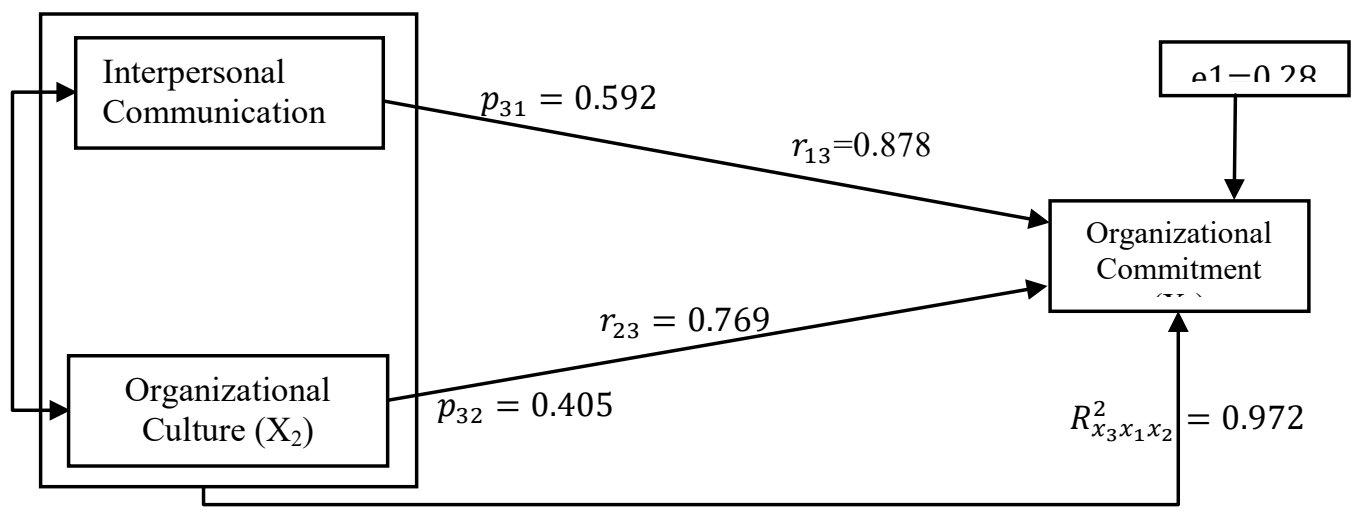

Picture1. Theoretical Model of Research Variable

\subsection{Discussion}

Some steps have been done due to the description data and hypothesis test below. Firstly, the significance path coefficient was gained between interpersonal communication and organizational commitment to 0.592 . It reflects that teachers' interpersonal communication in an organization will determine higher changes of the organizational commitment. Candor and sharing may emerge through communication. These, moreover, may develop to psychological level and make people change other peoples' healthy feelings having communication with them. Pledge and responsibility from the member of the organization can be achieved through good interpersonal communication to attain the vision of the organization effectively and efficiently.

Many studies supported this finding such as a study conducted by Hassan Zarel Martin, et.all. Showed that there is a significant correlation between interpersonal communication and organizational commitment [16]. There is a direct interpersonal communication correlation of chive or leader of an organization on members' organizational commitment on the influence of 0.3 [17]. Interpersonal communication has a big effect on organizational commitment [18]. The relation of communication social group environment affects people commitment to an interpersonal and social group environment. The power of communication on commitment is 
truly determined by how close the relationships among people to keep their relationship with their social group environment: the closer and the more necessary they have, the stronger communication influences the commitment, and vice versa.

Secondly, the path coefficient significance between organizational culture and organizational commitment was on $\mathrm{p}_{32}, 0.405$. This finding proved that the changes in organizational commitment are determined by the organizational culture. This finding, moreover, indicated that every provision (values, beliefs, rules) that the members of the organization must comply with is in realizing the goals of the organization will affect organizational commitment.

This finding was supported by Johny Tarore showed that organizational culture gives a direct influence on organizational commitment on 0.32 [19]. It indicates that organizational culture is able to determine the organizational commitment and however, support the theory proposed by Baron and Greenberg that explained that direct influence of organizational culture on organizational commitment.

Thirdly, the calculation was simultaneously gained by direct interpersonal communication and organizational culture on organizational commitment with correlational coefficient on $\mathrm{R}=0.972$. Therefore, interpersonal communication and organizational culture directly affect positively the organizational commitment together. It means that interpersonal communication potentially has great influence to persuade people because we are able to use our senses to increase our level of persuasion message. Positive implication is also expected from well communication between members of the group in an organization to create a strong and productive organizational culture. Organizational culture, moreover, influences the habit of members of an organization which then determine the integrity of members of an organization.

Interpersonal communication and organizational culture are two variables that have a relationship, and both have a significant effect on organizational commitment. The results of this study are in line with the research conducted by Benyamin Situmorangstating that interpersonal communication and organizational culture have a direct positive effect on organizational commitment [20]. In addition, it concluded that organizational culture has a total influence on organizational commitment [21].

\section{Conclusion}

Based on the previous result and discussion, it can be concluded as follow: (1) interpersonal communication gives direct positive and significant effect toward organizational commitment; (2) organizational culture is a direct positive and significant effect on organizational commitment; (3) interpersonal communication and organizational culture simultaneously give effect on organizational commitment.

\subsection{Implication}

The way that can be applied to improve interpersonal communication in order to influence the improvement of organizational commitment by having a good social relationship to convey information about the goals that want to be reached and task or role that can be done by each individual that is involved in an agenda in order that they are able to work effectively and efficiently. The next, when they communicate they have an emphatic attitude. Emphatic has important role in communication that is when a teacher is able to place himself on the situation or condition that is faced by another person. If this habit is applied continuously, the 
members will give comfort to other members in the organization, happy on the organization and it will increase members' commitment in the organization.

The way that needs to do to improve organizational culture such as ruhul jihad spirit.Ruhul jihad as one of the core values organization culture which the existence should be defended and developed in every aspect of organization management. Therefore, it should be applied ruhul jihad is power, that is ruhul jihad as the main power to bring the organization getting better and civilized. Moreover, if the ruhul jihad principal then applied and transformed (sharing ruhul jihad is more powerful) in the daily life that color every organization managerial element, surely it will bring abundant productive changes for organization development in creating a superior quality organization.

\subsection{Suggestion}

Firstly, PGRI organization committee can use this research finding as consideration to develop human resources, especially in increasing teacher organization commitment through improving interpersonal communication, teacher organization culture of public Senior High School at Madura Island.

Secondly, PGRI organization committee gives an opportunity for teachers to join various programs and extracurricular activity. That program and activity will be useful for teachers to improve commitment on the organization in the future.

Thirdly, headmaster should socialize the teachers about the importance of being active to join PGRI activity, to be able to do their duty well, responsible, and can be relied on central government, regional government, and society.

\section{References}

[1] Kunandar, Guru Profesional. Jakarta: Rajawali Press, 2014.

[2] U. S. Saud, Pengembangan Profesi Guru. Bandung: Alfabeta, 2013.

[3] F. Luthans, Organizational Behavior. New York: Mc Graw Hill, 2011.

[4] J. A. Colquitt, J. Lepine, and M. J. Wesson, Organizational Behavior Improving Performance and Commitment in the Workplace. USA: Mc Graw-Hill Education, 2011.

[5] A. Kinicki and Robert Kreitner, Organizational behavior: Key concepts, skills \& best practices. Boston: McGraw Hill, 2003.

[6] R. A. Baron and J. Greenberg, Behavior in Organization: Understanding and Managing The Human Side of Work, 9th ed. Toronto: Allyn and Bacon, 1990.

[7] P. Suprastowo, "Kajian Tentang Tingkat Ketidak hadiran Guru Dan Dampaknya Terhadap Siswa," J. Pendidik. dan Kebud., vol. 19, no. 1, pp. 31-49, 2013.

[8] S. P. Robbins and M. Coulter, Management, 11th ed. New Jersey: Prentice Hall, 2012.

[9] J. T. Wood, Interpersonal Communication. USA: Cengage, 2010.

[10] D. Solomon and J. Theiss, Interpersonal Communication: Putting Theory into Practice. New York: Routledge Taylor \& Francis Group, 2012.

[11] A. Liliweri, Komunikasi Antarpersonal. Jakarta: Kencana, 2015.

[12] M. Morissan, Psikologi Komunikasi. Bogor: Ghalia Indonesia, 2010.

[13] S. P. Robbins and T. A. Judge, Perilaku Organisasi. Jakarta: PT Indeks Kelompok Gramedia, 2006.

[14] M. E. Sari, "The Role Of Learning Management Of Islamic Boarding School (Pesantren) In Improvement Of Their Students Religious Tolerance In West Java- 
Indonesia,” Int. J. Innov. Appl. Stud., vol. 19, no. 1, pp. 24-32, 2017.

[15] R. Kreitner, Management: A problem-solving process. Boston: Houghton Mifflin Harcourt, 1980.

[16] H. Z. Matin, G. Jandaghi, F. H. Karimi, and A. Hamidizadeh, "Relationship between Interpersonal Communication Skills and Organizational Commitment (Case Study: Jahad Keshavarzi and University of Qom, Iran)," Eur. J. Soc. Sci., vol. 13, no. 3, pp. 387-398, 2010.

[17] F. Setyono, "Pengaruh Kualitas Komunikasi Interpersonal Pemimpin Kelompok Sel Terhadap Komitmen Organisasi Anggota Kelompok Sel di Satelit Holy Gereja Mawar Sharon Surabaya," J. E-Komunikasi Vol. I, vol. 1, no. 2, 2013.

[18] I. Hutagulung, "Pengaruh Kecerdasan Emosional, Komunikasi Interpersonal, Komitmen Organisasi terhadap Manajemen Stres Kerja (Universitas Mercua Buana," J. Interak., vol. 3, no. 2, 2014.

[19] A. Ikhwan, "Metode Simulasi Pembelajaran dalam Perspektif Islam, Istawa:," $J$. Pendidik. Islam, vol. 2, no. 3, pp. 1-34, 2017.

[20] A. Ikhwan, "Penerapan Manajemen Hubungan Sekolah dan Masyarakat dalam Perspektif Islam," Al-HayatJournal Islam. Educ., vol. 2, no. 1, pp. 1-16, 2018.

[21] A. Ikhwan, "Integrasi Pendidikan Islami (Nilai-Nilai Islami dalam Pembelajaran)," Ta'allum J. Pendidik. Islam, vol. 2, no. 2, pp. 179-194, 2014. 